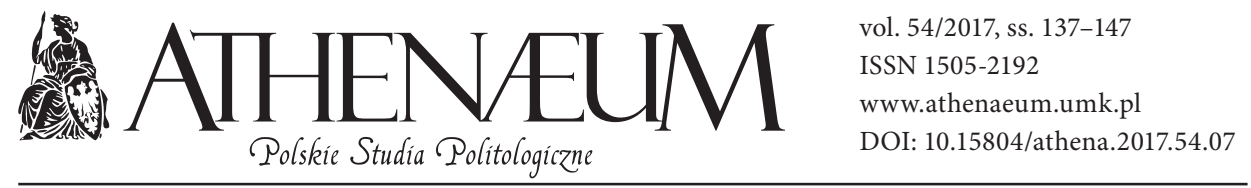

\title{
BEZPIECZEŃSTWO SPOŁECZNOŚCI LOKALNYCH W DOKUMENTACH PROGRAMOWYCH WYBRANYCH PARTII STARTUJACCYCH W WYBORACH PARLAMENTARNYCH 2015 ROKU
}

\author{
THE ISSUE OF SECURITY OF LOCAL COMMUNITIES \\ IN PROGRAM PROPOSALS OF THE SELECTED POLITICAL PARTIES \\ BEING CANDIDATES IN PARLIAMENTARY ELECTIONS OF 2015
}

Patryk Tomaszewski*

\begin{abstract}
ABSTRAKT
Celem artykułu jest wskazanie rozwiązań dotyczących zapewnienia bezpieczeństwa społeczności lokalnych zawartych w dokumentach programowych następujących partii politycznych: Prawo i Sprawiedliwość, Platforma Obywatelska RP , Nowoczesna Ryszarda Petru, Zjednoczona Lewica, Polskie Stronnictwo Ludowe, Partia Razem, Koalicja Odnowy Rzeczypospolitej Wolność i Nadzieja, a także ruchu społecznego, a obecnie stowarzyszenia Kukiz 15. Autor wyróżnił najważniejsze składowe bezpieczeństwa społeczności lokalnych; należą do niego: bezpieczeństwo przestrzeni (infrastruktura drogowa, miejsca wypoczynku, architektura, oświetlenie); bezpieczeństwo publiczne jest rozumiane jako gwarancja niezakłóconego funkcjonowania zarówno obywateli, jak i instytucji; bezpieczeństwo ekologiczne; dostęp do usług, świadczeń,
\end{abstract}

The aim of the present paper is to point to some solutions to the provision of security to local communities, the solutions being contained in the program proposals of the following political parties: Prawo i Sprawiedliwość, Platforma Obywatelska RP, Nowoczesna Ryszarda Petru, Zjednoczona Lewica, Polskie Stronnictwo Ludowe, Partia Razem, Koalicja Odnowy Rzeczypospolitej Wolność i Nadzieja as well as the social movement - and currently an association - Kukiz 15. The author distinguished the most important constituents of the security of local communities. They encompass what follows: area security (road infrastructure, entertainment area, architecture, lighting); public security as conceived of as the warranty of the undisturbed actions of both citizens and institutions; ecological security; the access to services, welfare and institutions; the economic security of the local community.

* Uniwersytet Mikołaja Kopernika w Toruniu, Wydział Politologii i Studiów Międzynarodowych. 
instytucji; bezpieczeństwo ekonomiczne społeczności lokalnej.

W tekście autor postara się odpowiedzieć na pytanie, czy w programie partii politycznych bezpieczeństwo społeczności lokalnych było wyartykułowane i stanowiło wyróżniony fragment programu. Jak dużo związana z nim problematyka zajmowała miejsca. Na jakich elementach bezpieczeństwa skupiały się środowiska polityczne podczas wyborów parlamentarnych w 2015 roku.

Słowa kluczowe: bezpieczeństwo publiczne, bezpieczeństwo społeczności lokalnych, wybory parlamentarne
In the paper, I will attempt to answer the question whether in the program proposals of the said political parties the security of local communities was well-articulated and whether it was an underlined fragment thereof. Moreover, I will investigate the question how much space the security-related issues occupied and what constituents of the security the political circles focused on during the parliamentary elections of 2015 .

Keywords: public security, security of local communities, parliamentary elections

W pewnym uproszczeniu można wskazać, że bezpieczeństwo społeczności lokalnych rozumiemy jako stan braku obiektywnych zagrożeń zbiorowości zamieszkującej niewielkie terytorium, połączonej silnymi więzami partykularnymi, poczuciem przywiązania do miejsca, w którym się żyje, jego tradycji, historii, a także chęcią dbałości o wielowymiarowe bezpieczeństwo na tej przestrzeni. Lokalność rozumieć można jako związek terytorialny - pewnego umiejscowienia w przestrzeni, przynależność do pewnego krajobrazu. Jest to również związek emocjonalny. Przestrzeni rozumianej jako obszar zajmowany i użytkowany przez daną zbiorowość. Poprzez terytorium rozumieć można: wspólnotę czy spółdzielnię mieszkaniową, ulicę lub ich zbiór, osiedla, sołectwo, parafię, dzielnice, gminy, powiat, w niektórych ujęciach województwo czy obszary regionów na styku kilku województw, a nawet obszary transgraniczne. Ujęcie społeczności lokalnej wykracza jednak poza ramy administracyjne, porządkujące wspólnoty lokalne. Przestrzenie mogą przybierać charakter geograficzny, ale i historyczny. Ważnym elementem jest tożsamość terytorialna. Możemy mówić o trzech jej wymiarach - pierwszy z nich jest przypisany przez fakt urodzenia się w nim, drugi, nabyty w procesie socjalizacji i kauteryzacji, i trzeci, świadomie wybierany w akcie tworzenia tożsamości samoświadomościowej (Rylka, 2010, s. 9). W literaturze przedmiotu rozróżniam dwa pojęcia „zbiorowości terytorialnej” i „wspólnoty terytorialnej”. W pierwszym przypadku podstawową więzią społeczną jest terytorium rozumiane jako wspólna wartość i korelat stosunków społecznych, a więc wieź emocjonalną połączoną z przekonaniami odnoszącymi się do tego terytorium jako części przestrzeni społecznej. Natomiast w drugim 
przypadku mówimy o wspólnocie, która posiada zaawansowany proces integracji kulturowej i społecznej. Wspólnota terytorialna jest zatem grupą ideologiczną (Rylka, 2010, s. 23). Można powiedzieć, że wspólnota terytorialna ma poczucie zakorzenienia. Tożsamość regionalna i per analogiam lokalna są specyficznymi przypadkami tożsamości społecznej i kulturowej (symbolicznej), gospodarczej, ale również - o czym była już mowa - topograficznej. Tożsamość lokalną i regionalną opisywać można w kilku perspektywach:

- psychologicznej - kluczowy jest stopień indywidualnej identyfikacji, często wyrażanej w altruistycznych działaniach;

- socjologicznej - konstytutywny staje się w tej perspektywie element świadomościowy oparty na antynomii: my - oni, a więc oparty na poczuciu odrębności;

- ekonomicznej - szczególnie ważna w wymiarze gospodarki rynkowej odnosząca się do gospodarki regionalnej;

- politologicznej - odnosi się do preferencji politycznych, do wyborów regionalnych, ale również chodzi w niej o tradycje polityczne;

- historycznych - powiązanie z bohaterami z regionu, instytucjami historycznymi;

- antropologicznej i etnograficznej - istotnym wyznacznikiem tożsamości staje się strój, obyczaje, symbole kultury materialnej;

- geograficznej - przypisanie do terytorium;

- urbanistyczno-architektonicznej - czynnikiem konstytuującym ją są np. specyficzne rozwiązania urbanistyczne (Szczepański, 2005, s. 129-130).

Przykładami wspólnot związanych silną tożsamością, odpowiedzialnością są chociażby mieszkańcy: Kaszub, Podhala, a może w trochę mniejszym stopniu Kociewia, Pałuk, Orawy itp.

W zdefiniowaniu społeczności lokalnej ważnymi czynnikami będą: także typ społeczności (chociażby podział: miejska - wiejska, czy też antynomia: społeczność tradycyjna - nowoczesna) oraz więzy emocjonalne, jakie zachodzą między ludźmi na danym obszarze.

Bezpieczeństwo na poziomie lokalnym jest wielowymiarowe i odzwierciedla potrzeby danej grupy. Do jego najistotniejszych elementów należą:

- bezpieczeństwo przestrzeni (infrastruktura drogowa, miejsca wypoczynku, architektura, oświetlenie);

- bezpieczeństwo publiczne jest rozumiane jako gwarancja niezakłóconego funkcjonowania zarówno obywateli, jak i instytucji;

- bezpieczeństwo ekologiczne; 
- dostęp do usług, świadczeń, instytucji;

- bezpieczeństwo ekonomiczne społeczności lokalnej

Celem artykułu jest wskazanie rozwiązań dotyczących zapewnienia bezpieczeństwa społeczności lokalnych zawartych w dokumentach programowych następujących partii politycznych: Prawo i Sprawiedliwość, Platforma Obywatelska RP, Nowoczesna Ryszarda Petru, Zjednoczona Lewica, Polskie Stronnictwo Ludowe, Partia Razem, Koalicja Odnowy Rzeczypospolitej Wolność i Nadzieja, a także ruchu społecznego, a obecnie stowarzyszenia Kukiz 15. Autor postara się odpowiedzieć na pytanie, czy w programie partii politycznych bezpieczeństwo społeczności lokalnych było wyartykułowane i stanowiło wyróżniony fragment programu oraz jak wiele związana z nim problematyka zajmowała miejsca. Autor postara się znaleźć informacje, na jakich elementach bezpieczeństwa skupiały się środowiska polityczne. Hipoteza mówi: partie o profilu centrowym i lewicowym więcej miejsca poświęcają problematyce bezpiecznej i przyjaznej przestrzeni od środowisk prawicowych. Hipoteza poboczna: zagadnienia bezpieczeństwa społeczności lokalnych są rzadko podejmowane w dokumentach programowych na szczeblu ogólnopolskim, a częściej ze względu na charakter wyborów podejmowane są podczas wyborów samorządowych. Metoda zastosowana w niniejszym artykule to krytyczna analiza tekstu.

W naukach o polityce coraz częściej pojawiają się opinie, że tradycyjny podział na prawicę i lewicę w odniesieniu do partii politycznych jest nieprecyzyjny. Roman Bäcker zauważył, że niemożliwe jest stworzenie „takiej definicji prawicy i lewicy, która obejmowałaby wszystkie przypadki ugrupowań, które są tak nazywane albo się autoidentyfikują jako takie" (Bäcker, 2011, s. 146). W tych rozważaniach bliższy jednak będzie pogląd Norberto Bobbio, który stwierdził, że „Prawica i lewica to dwa terminy antytetyczne, od ponad dwóch stuleci używane powszechnie w celu wskazania sprzeczności pomiędzy ideologiami i ruchami, na jakie podzielone jest głęboko skonfliktowane uniwersum myśli i działań politycznych" (Boobio, 1996, s. 25). Oczywiście przyglądając się poszczególnym kategoriom dystynktywnym dla prawicy i lewicy - można zauważyć, że odwołują się do wartości zarówno prawicowych, jak i lewicowych, mimo konkretnej identyfikacji tych ugrupowań.

${ }^{1} \mathrm{~W}$ szerokim ujęciu będzie to również bezpieczeństwo zdrowotne, a nawet w pewnym sensie militarne. W artykule jednak autor skupi się na bezpieczeństwie przestrzeni oraz bezpieczeństwie publicznym, a także niektórych elementach bezpieczeństwa ekonomicznego społeczności lokalnej. 
Niemniej polska scena polityczna, zdaniem autora, nadal generalnie przypomina tradycyjny podział na prawicę i lewicę, chociaż trudno nie zauważyć, że mamy ugrupowania, które trudno jednoznacznie sklasyfikować, jak chociażby Polskie Stronnictwo Ludowe, Nowoczesna, czy środowisko Kukiz 15. Faktem jest też, że w wielu sprawach zaciera się wyrazistość poglądów różnych partii politycznych, a różnice odnoszą się przede wszystkim do spraw światopoglądowych. W celu porządkującym autor przyjął, że prawicową partią konserwatywno-liberalną była Koalicja Odnowy Rzeczypospolitej Wolność i Nadzieja, o profilu niepodległościowym i socjalnym, ale z elementami prawicowymi, w kontekście światopoglądowym to Prawo i Sprawiedliwość, zaś partiami centrowymi, które łączyły postulaty liberalne z odniesieniami do solidaryzmu społecznego w kwestiach gospodarczych z jednoczesnym podkreślaniem laickości były: PO i Nowoczesna, gdzie - zdaniem autora - bardziej na lewo przesunięta była partia Ryszarda Petru. Znacznie trudniej, nawet w uproszczeniu, zakwalifikować Polskie Stronnictwo Ludowe, gdyż partia ta należy do ugrupowań o malejącym znaczeniu, której elektorat stanowi konkretna grupa wyborców, w tym przypadku głównie rolników, a program partii jest raczej centroprawicowy, zważywszy chociażby na odwołania do tradycji. Jednocześnie jednak nie można zapominać, że ugrupowanie to w poprzedniej kadencji przyjęło do swojego klubu sporą grupę działaczy Twojego Ruchu Janusza Palikota. Środowisko skupione wokół Pawła Kukiza podczas wyborów reprezentowało w większości poglądy różnych nurtów tradycyjnie usytuowanych na prawicy - jak frakcje konserwatywno-liberalne, republikańskie, narodowe, ale doszukać się można także zalążka idei o charakterze patriotyczno-lewicowym, reprezentowanym przez Kornela Morawieckiego.

Wybory parlamentarne, które odbyły się 25 października 2015 roku, dość poważnie zmieniły polską scenę polityczną. Poza parlamentem znalazła się Zjednoczona Lewica, a większość parlamentarną uzyskała jedna partia: Prawo i Sprawiedliwość. Pojawił się nowy gracz w postaci Nowoczesnej Ryszarda Petru oraz środowiska niejednorodnego ideowo, skupionego wokół muzyka Pawła Kukiza.

Koncepcje bezpieczeństwa społeczności lokalnych są często kompatybilne z kilkoma postulatami o charakterze ustrojowym, jak np. decentralizacji władzy, wzmocnienia roli samorządów terytorialnych, czy też przenoszenia instytucji państwowych w różne miejsca kraju w celu niwelacji różnic między centrum a peryferiami. Spory wpływ mają także koncepcje socjologii miasta czy też urbanistyki, jak chociażby „Teoria rozbitych okien” czy też „Crime prevention through urban design". 
W obszernym programie Prawa i Sprawiedliwości przede wszystkim można wyeksponować kilka zagadnień zwanych bezpieczeństwem społeczności lokalnych. Są to zmiany w strukturze samorządu opierające się na pomyśle stworzenia województwa warszawskiego w celu wzmocnienia rozwoju reszty Mazowsza (Zdrowie, praca, rodzina, 2015, s. 53). Widziano bowiem dysproporcję między środkami finansowymi przeznaczonymi na rozwój stolicy i zupełnie innymi na tereny województwa mazowieckiego. Ponadto program PiS odwołuje się do pojęcia „zrównoważonego rozwoju”, rozumianego jako wspieranie potencjału „Polski powiatowej i gminnej” (Zdrowie, praca, rodzina, 2015, s. 53). W tym ujęciu zrównoważony rozwój miał mieć charakter ekonomiczny - zrównywanie dostępności do zasobów oferowanych przez państwo, a nie do teorii ekologicznych idei ograniczonych możliwości. Także Polskie Stronnictwo Ludowe odnosiło się do postulatów zrównoważonego rozwoju, w programie tej partii zapisano: „Stawiamy na zrównoważony rozwój poszczególnych regionów, ośrodków wielkomiejskich i prowincji; na spójność terytorialną, która jest tak samo ważna, jak spójność ekonomiczna i społeczna. Dla zrównoważonego rozwoju istotne znaczenie ma rozwój sektora usług, w tym szczególnie związanych z naszym codziennym funkcjonowaniem (usługi zdrowotne, socjalne i środowiskowe)" (Deklaracja wyborcza PSL, 2015, s. 26). W ujęciu PSL-u zrównoważony rozwój miał obejmować również środowisko naturalne.

Ciekawy pomysł proponowało środowisko Pawła Kukiza, które chciało, aby część instytucji centralnych, podobnie jak np. w Niemczech, przenieść poza Warszawę, aby wzmocnić inne ośrodki miejskie, a ponadto przybliżyć problemy mieszkańców innych regionów elitom politycznym i administracyjnym (Strategia zmiany Kukiz 15, 2015, s. 14). W programie PiS zapisano: „Dążąc do poprawy jakości demokracji lokalnej, spełnimy coraz powszechniejszy postulat ustawowego ograniczenia w czasie - do dwóch kadencji - nieprzerwanego pełnienia tej samej funkcji przez wójtów, burmistrzów i prezydentów miast; po przerwie trwającej co najmniej jedną kadencję zainteresowana osoba będzie mogła kandydować na to samo stanowisko ponownie" (Zdrowie, praca, rodzina, 2015, s. 53). Celem tego zabiegu miało być zwiększenie fluktuacji władz samorządowych i swoiste „odbetonowanie” zastałych zależności i powiązań. Podobny postulat pojawił się w programie Partii Razem (Razem inna polityka jest możliwa, 2015). Nie zauważano w tych środowiskach, że takie rozwiązanie ogranicza bierne prawo wyborcze.

W obszarze infrastruktury Prawo i Sprawiedliwość postulowało budowę szybkich połączeń między dużymi miastami, ale co znacznie ważniejsze z punktu 
widzenia społeczności lokalnej - obwodnic dużych miast, a także podkreślano potrzebę zniesienia wykluczenia komunikacyjnego w odniesieniu do mieszkańców wschodnich województw poprzez szybką realizację na tych terenach programu budowy dróg, a ponadto w celu ograniczenia ruchu kołowego - w programie znalazł się postulat głoszony od lat 90. minionego wieku przez środowiska ekologów, który sprowadzić można do hasła: „Tiry na tory” (Zdrowie, praca, rodzina, 2015, s. 83-86). Idąc dalej, w odniesieniu do zagadnień związanych jednocześnie z ekologią i energetyką, a więc wywodzących się z bezpieczeństwa ekonomicznego, zauważano potrzebę wykorzystania krajowych źródeł odnawialnych: biomasa, odpady komunalne, fotowoltaika, hydroenergetyka. Zapowiedziano potrzebę usytuowania elektrowni wiatrowych w odległości $3 \mathrm{~km}$. od zabudowań, co wiązało się z postulatami osób, które mieszkały w bezpośrednim kontakcie z elektrowniami wiatrowymi i twierdziły, że odczuwają negatywne skutki oddziaływania wiatraków.

Na obszarach wiejskich postulowano - poza zwiększeniem nakładów finansowych w ich rozwój - przede wszystkim pozostawienie na tych terenach, jak to zapisano w programie ,instytucji państwowych”: szkół (które przecież finansuje przede wszystkim samorząd), placówek pocztowych, komisariatów policji. Dużo miejsca poświęcono na tematy związane ze średnią i małą przedsiębiorczością, czy też wzmocnieniem potencjału rodziny. W programie pojawiły się także odniesienia do budowy społeczeństwa obywatelskiego. Twórcy programu zauważali, że są zwolennikami wspierania inicjatyw obywatelskich finansowo, gdyż to pobudza ich zaangażowanie. Proponowali również powołanie Funduszu Inicjatyw Obywatelskich wspierającego działania na szczeblach lokalnych i regionalnych (Zdrowie, praca, rodzina, 2015, s. 143). Ciekawe jest, że również PO proponowało utworzenie nawet identycznego z nazwy Funduszu Inicjatyw Obywatelskich. Pisano o nim w programie PO: „Poprzez ogólnokrajowy konkurs na najciekawszą inicjatywę lokalną pobudzimy zainteresowanie samorządów wykorzystaniem funduszu sołeckiego do rozwiązywania problemów lokalnych społeczności. Pomoże to integrować lokalne społeczności wokół wspólnych spraw. Przy wykorzystaniu Funduszu Inicjatyw Obywatelskich umożliwimy pozyskanie środków na działalność jednostek ochotniczych straży pożarnych, ale też organizacji nieformalnych, takich jak koła gospodyń wiejskich. W tych przypadkach będziemy dostarczać wsparcia za pośrednictwem lokalnych grup działania i lokalnych grup rybackich, których doświadczenie, potencjał i znajomość potrzeb lokalnych musimy koniecznie wykorzystać. W ten sposób ochronimy przed zapomnieniem lokalną kulturę, tradycję i zwyczaje" (Polska przyszłości, 2015, s. 62). 
Trudno szukać podobnych pomysłów politycznych w programie założonej przez Janusza Korwin-Mikke partii Koalicja Odnowy Rzeczypospolitej Wolność i Nadzieja. W odniesieniu do bezpieczeństwa społeczności lokalnej, skupiono się na sprawach związanych z porządkiem publicznym. Odniesiono się do cnót republikańskich, związanych również z poczuciem odpowiedzialności za bezpieczeństwo przez obywateli. W programie pisano: „Obywatel musi umieć się bronić przed różnymi zagrożeniami, inaczej nie będzie wolny, a zdany na pomoc innych obywateli lub łaskę obcych państw. Konieczna jest odbudowa systemu powszechnych szkoleń dla obywateli, związanych z ochroną życia, mienia i kraju" (Dumna, bogata Polska, 2015). W środowisku tym dość powszechne jest przekonanie o rozszerzeniu dostępu do broni przez obywateli. Nieobce są też idee patroli sąsiedzkich.

Natomiast w programie Zjednoczonej Lewicy stosunkowo niewiele miejsca poświęcono bezpośrednio zagadnieniom związanym ze wspólnotami lokalnymi, przede wszystkim skupiono się na wątkach odnoszących się do rynku pracy i polityki socjalnej. Na marginesie pojawiły się jednak takie sprawy, jak poprawa jakości życia mieszkańców obszarów wiejskich (Program wyborczy Zjednoczona Lewica, 2015, s. 28), czy też propozycje wykorzystania energii odnawialnej. Podobne odniesienia można było znaleźć w programie PSL. Ludowcy zaznaczali również, że należy stawiać na unowocześnienie wsi. Wspominano o rozwoju samorządów, ale zauważano, że nie należy powierzać im kolejnych zadań bez zapewnienia środków finansowych. Interesujące z punktu widzenia społeczności lokalnych były natomiast postulaty mówiące o tożsamości społeczno-kulturalnej. Zapisano: „Istotny wpływ na rozwój życia społeczno-kulturalnego, szczególnie w Polsce lokalnej i na wsi, mają dotychczas funkcjonujące organizacje, m.in.: Ochotnicze Straże Pożarne, Ludowe Zespoły Sportowe, Koła Gospodyń Wiejskich, a także nowo powstające stowarzyszenia, grupy integracyjne, które urozmaicają życie społeczno-kulturalne mieszkańców. W kreowaniu rozwoju małych ojczyzn aktywne są Lokalne Grupy Działania, wspierane ze środków unijnych" (Deklaracja wyborcza PSL, 2015, s. 28). Również w programie PO znalazł się oddzielny rozdział poświęcony rozwojowi wsi i małych miast.

W programie partii Ryszarda Petru przede wszystkim odnoszono się do zwiększenia roli samorządu terytorialnego, zmniejszenia liczby radnych, przy jednoczesnej ich profesjonalizacji, a także pojawił się postulat związany z ruchami miejskimi - partycypacji społecznej, a także koncepcja smart cities (Nowoczesna Polska teraz, 2015, s. 12), czyli idea poprawy życia miejskiego poprzez wprowadzanie bardziej zrównoważonych i zintegrowanych rozwiązań. 
Poprzez smart cities rozumie się: stosowanie innowacji, lepsze planowanie przestrzenne, bardziej partycypacyjne podejście, wyższą efektywność energetyczną, lepsze rozwiązania komunikacyjne, inteligentne wykorzystanie technologii informatycznych. Podobne rozwiązanie proponowała w 2015 roku Platforma Obywatelska (Polska przyszłości, 2015, s. 50). W jej programie podkreślano, że zostanie również utworzona Księga Dobrych Praktyk dla samorządów.

W programie Partii Razem, znalazło się sporo zapisów mających odniesienia do bezpieczeństwa społeczności lokalnych. Razem, jako partia o charakterze wyraźnie lewicowym, w programie zawarła sporo postulatów związanych z rozwojem infrastruktury drogowej, szczególnie w miejscach, gdzie nadal były drogi gruntowe, które utrudniły dojazd chociażby służbą do potrzebujących pomocy. Poza tym komunikacja miała wpłynąć na ożywienie pewnych miejsc, stąd pojawił się postulat dofinansowania połączeń regionalnej komunikacji autobusowej. Podobnie jak Prawo i Sprawiedliwość, Partia Razem postulowała powstrzymanie likwidacji szkolnych i lokalnych bibliotek, a także rozwój szkolnictwa w mniejszych miejscowościach. Założenia te miały niwelować różnice między Polską A i B (Razem inna polityka jest możliwa, 2015).

Stosunkowo dużo miejsca porządkowi publicznemu poświęciła w swoim programie Platforma Obywatelska, która wskazywała, że nastąpi modernizacja komend i komisariatów policji, a ponadto większy nacisk zostanie położony na pracę dzielnicowych, którzy współpracować będą z mieszkańcami w przydzielonych im rejonach (Polska przyszłości, 2015, s. 77). Podobny postulat głosiło środowisko Kukiz 15. Zauważano, że funkcjonariusze policji muszą znaleźć się bliżej spraw społeczności lokalnych, a ma to nastąpić poprzez odbiurokratyzowanie tej formacji mundurowej. Proponowano także wybór Komendantów Powiatowych przez społeczność lokalną (Strategia zmiany Kukiz 15, 2015, s. 31).

W programach partii politycznych, zważywszy na charakter wyborów, nie pojawiały się bezpośrednie odniesienia do bezpieczeństwa społeczności lokalnych. Niemniej ugrupowania startujące w wyborach podnosiły takie kwestie, jak: rozwój drogownictwa szczególnie w małych gminach (Razem, PO, PiS, PSL). Zmiany w samorządzie mogące przybliżyć jego działanie obywatelom miały być wprowadzone na drodze realizacji różnych pomysłów: od stworzenia nowego województwa warszawskiego (PiS), do decentralizacji urzędów publicznych, celem wzmocnienia innych niż stolica ośrodków miejskich. Natomiast postulat konieczności zrównania rozwoju między Polską A i B najwyraźniej był podkreślony we wskazaniach programowych PiS i Partii Razem. Ciekawe jest, że Platforma Obywatelska i środowisko Kukiz 15 zwracały uwagę na porządek 
publiczny i rolę w jego zapewnieniu dzielnicowych będących blisko mieszkańców. Faktem jest, że do tematyki związanej z przestrzenią, sprawami społeczności lokalnej, a szczególnie w ujęciu smart cities - nawiązywały dwie partie centrowe: PO i Nowoczesna, co potwierdza postawioną we wstępie hipotezę. Wynikało to prawdopodobnie z faktu, że program skierowany był do ludzi młodych i w średnim wieku mieszkających w dużych ośrodkach, którzy mogli potencjalnie znać rozwiązania związane $\mathrm{z}$ inteligentnymi miastami, a przynajmniej mogłoby potencjalnie ich zainteresować takie podejście do zarządzania miastem. Wybory ogólnopolskie nie sprzyjały formułowaniu dużej ilości postulatów związanych ze społecznościami lokalnymi, widać wyraźnie jednak, że zarówno obszary wiejskie, jak i sprawy samorządowe pozostawały w zainteresowaniu twórców programów politycznych.

Pewne jest, że w wyborach samorządowych w 2018 roku znacznie więcej uwagi zostanie poświęconej różnym aspektom bezpieczeństwa społeczności lokalnej, przypuszczać też można, że programy te czerpać będą z doświadczeń Europy zachodniej i poświęcone w nich będzie sporo miejsca socjologii miasta. Bezdyskusyjne jest, że również zbliżone ideowo, szczególnie do Nowoczesnej i Partii Razem, ruchy miejskie będą miały większy wpływ na charakter programu tych formacji. Można przypuszczać, że mogą się w nich pojawić idee nie tylko związane ze „zrównoważonym rozwojem”, dziś wykorzystywane prawie przez wszystkie środowiska polityczne, ale również koncepcje np. „prawa do miast” - ukute przez francuskiego socjologa o neomarksistowskich poglądach Henri’ego Lefebvre'a, a rozumiane jako sprawiedliwe korzystanie z zasobów miasta w ramach zasad zrównoważonego rozwoju, równości, demokratyzmu i sprawiedliwości społecznej (Lefebvre, 2012).

\section{BiBLIOGRAFIA:}

Bäcker, R. (2011). Nietradycyjna teoria polityki. Toruń.

Bobbio, N. (1996). Prawica i lewica. Kraków.

Deklaracja wyborcza PSL. Blisko ludzkich spraw. (2015). Warszawa.

Dumna, bogata Polska, Program partii KORWiN. (2015). Pobrane z: https://www. partiakorwin.pl/program/.

Lefebvre, H. (2012). Prawo do miast. Praktyka teoretyczna, 5. Pobrane z: http://pressto. amu.edu.pl/index.php/prt/article/view/2774/2755.

Nowoczesna Polska teraz. Kierunki programowe lipiec 2015. (2015). Warszawa. Polska przyszłości. Program Platformy Obywatelskiej RP 2015. (2015). Warszawa. Program wyborczy Zjednoczona Lewica. (2015). Warszawa. 
Razem inna polityka jest możliwa. Program wyborczy 2015. (2015). Warszawa.

Rykiel, Z. (2010). Tożsamość terytorialna jako uczestnictwo w kulturze. W: Z. Rylka (red.), Tożsamość terytorialna w różnych skalach przestrzennych (23). Rzeszów.

Strategia zmiany Kukiz 15. Potrafisz Polska. (2015). Warszawa.

Szczepański, M. (2005). Społeczności lokalne i regionalne a ład kontynentalny i globalny. W: W. Wesołowski, J. Włodarek (red.), Kręgi integracji i rodzaje tożsamości. Polska, Europa, Świat. Warszawa.

Zdrowie, praca, rodzina. Program Prawa i Sprawiedliwości. (2015). Warszawa. 